\title{
TEMPORAL AND SPATIAL VARIATIONS OF SELECTED WATER QUALITY PARAMETERS IN SERGESTID SHRIMPS' HABITAT ALONG COASTAL WATER OF MIRI, SARAWAK, MALAYSIAN BORNEO
}

\author{
RUHANA HASSAN ${ }^{1,2^{*}}$ and MUHAMMAD NUR ARIF OTHMAN ${ }^{1}$ \\ ${ }^{1}$ Faculty of Resource Science and Technology, Universiti Malaysia Sarawak, \\ 94300 Kota Samarahan, Sarawak, Malaysia \\ ${ }^{2}$ Centre of Pre-University Studies, Universiti Malaysia Sarawak, \\ 94300 Kota Samarahan, Sarawak, Malaysia \\ *E-mail: hruhana@unimas.my
}

Accepted 14 July 2021, Published online 31 December 2021

\begin{abstract}
Evidences have shown that coastal water as habitat that support various flora and fauna as well as nursery ground which highlight the importance of water quality monitoring that act as basis for productivity of fisheries. Therefore, the objective of this study is to analyse the temporal and spatial variations of selected water quality parameters in sergestid shrimp's habitat along the coastal water of Miri, Sarawak. Nine water quality parameters namely dissolved oxygen (DO), temperature, turbidity, $\mathrm{pH}$, salinity, chlorophyll $a(\mathrm{chl} a)$, total suspended solid (TSS), nitrate $\left(\mathrm{NO}_{3}{ }^{-}\right)$and orthophosphate $\left(\mathrm{PO}_{4}{ }^{3-}\right)$ were measured in four stations along Miri coastal water. The variation explained by the principal component analysis had a total variance of 55.95\%. The PC1 shows that the waters in July 2017, September 2017, October 2017, December 2017 and January 2018 were characterized with high turbidity and TSS as well as low temperature and salinity. In contrast, stations in November 2017, March 2018 and April 2018 had warmer and clear water with high salinity reading, whereby blooms of sergestid shrimps were observed in March and April 2018. The PC2 result shows that in May 2017 and June 2017, coastal waters were characterized with low $\mathrm{pH}$ reading. Overall, the water quality parameters measured in all stations were close to the standard value of Class E of Malaysian Marine Water Quality Standards (MMWQS).
\end{abstract}

Key words: Biodiversity, coastal water, conservation, shrimp, water quality

\section{INTRODUCTION}

Coastal water is defined as an interface between the land and the water, composed of shallow waters, beaches, cliffs, coastal dunes, mangroves, coral reefs and seagrass beds (Cochard, 2016; Green \& Payne, 2017). This habitat is productive, serve as a nursery ground for diverse flora and fauna (Green \& Payne, 2017; Le Tissier et al., 2006). Besides, it acts as a natural barrier for the coastline against erosion rich with resources and generates economy for local people and countries (Burke et al., 2001; Cochard, 2016).

Miri is located in the northwestern of Sarawak, Malaysia, has an open coastline type facing the South China Sea, ranging from the Baram River

* To whom correspondence should be addressed. mouth till Tanjong Lobang (Ee \& Zae, 2010). The coastal water zone in Miri is made up of coral reef, beach forest, mangrove and peat swamp, cover areas of Sibuti, Baram, Senadin and Tudan. The specialty of Miri coastal water is a home for sergestid shrimp Acetes or locally known as 'Bubok'. Acetes is the main ingredient of 'belacan' and 'cincalok'. The presence of this shrimp during the peak season in February until April every year provides additional income to fishermen and the local community.

Currently, the coastal water is being threatened by anthropogenic factors such as land and sea pollution, overexploitation of natural resources, poor management to sustain the existing resources, tourism industry, residential development and other human activities (Burke et al., 2001; Tanjung et al., 2019). These additional factors may indirectly or directly change the environment and consequently 
disturb the natural dynamic of the ecosystem. The sudden change in the water quality due to the factors mentioned above could hinder fisheries productivity. Miri coastal waters are habitats for sergestid shrimps (Othman et al., 2020) but no detailed study on temporal and spatial water quality parameters may influence the shrimps' bloom phenomenon. Therefore, data obtained during this study is essential to monitor and determine the mitigation plan to support the conservation of this valuable resource.

\section{MATERIALS AND METHODS}

A total of 12 field samplings were conducted in four stations along the coastal water of Miri, Sarawak from May 2017 until April 2018 which covered Northeast monsoon (wet) and Southwest monsoon (dry). The coordinates for every station were recorded using Global Positioning System (GPSmap 62S, GARMIN) (Table 1). Figure 1 shows the location of sampling stations in Miri, Sarawak.

Five water quality parameters included dissolved oxygen (DO), temperature, turbidity, $\mathrm{pH}$ and salinity were measured in-situ during the daytime during the flood current. The field samplings were conducted during the interval, in between the neap and spring tides. The range of depth is between $1.7 \mathrm{~m}$ and 3.4 $\mathrm{m}$. Dissolved oxygen (DO) and temperature were measured using Hanna Instrument (Model HI9146). Turbidity was taken using Lutron (Model TU-2016). Sper Scientific (Model 300011) was used to record salinity while Hanna Instrument (Model HI 991003) was used to record $\mathrm{pH}$ reading. All the water quality parameters were recorded in the form of triplicates and further subjected to statistical analyses.

Four ex-situ water quality parameters namely chlorophyll $a$ (chl $a)$, total suspended solids (TSS), nitrate $\left(\mathrm{NO}_{3}{ }^{-}\right)$and orthophosphate $\left(\mathrm{PO}_{4}{ }^{3-}\right)$ were involved in this study. The water samples were collected at the $0.5 \mathrm{~m}$ depth from the surface using polyethylene bottles during the daytime during flood current, kept in a cooler box with ice and brought back to the laboratory in Universiti Malaysia Sarawak (UNIMAS) for further analyses.
At the laboratory, the water samples for $\operatorname{chl} a$ analysis were filtered through a filter paper (Whatmann, GF/C, $1.2 \mu \mathrm{m}$ pore size) and further processed following Aminot and Rey (2000). The water samples for TSS analysis were also filtered through similar pore size filter paper and further processed following Jacobs (2010). The filtered water samples were used for nutrient analysis namely $\mathrm{NO}_{3}{ }^{-}$ and $\mathrm{PO}_{4}{ }^{3-}$, further processed following the standard protocol (Hach, 2007) using Hach, DR 2010 spectrophotometer. IBM SPSS Statistics 21 was used to perform a two-way analysis of variance (ANOVA) with a significant value at $p<0.05$. Principal Component Analysis (PCA) was performed using PAST software Version 3.26 to determine the variation of selected water quality parameters among sampling stations and sampling months.

\section{RESULTS}

Figure 2 shows the trend of selected in-situ water quality parameters in Miri coastal water from May 2017 until April 2018. The overall range of water qualities measured was shown in Table 2. Based on two-way ANOVA analysis, all the water quality parameters recorded in this study shows a significant difference between sampling stations and sampling months with $p<0.05$. Water temperature ranged between $26.9 \pm 0.2^{\circ} \mathrm{C}$ and $33.2 \pm 0.1^{\circ} \mathrm{C}$ (Figure $2 \mathrm{a}$ ). Dissolved oxygen recorded the highest reading in February 2018 (ST4) with value of $7.31 \pm 0.61 \mathrm{mg} / \mathrm{L}$ (Figure 2b). $\mathrm{pH}$ in the middle year of 2017 recorded readings close to 7.0 in all the sampling stations (Figure 2c). Salinity recorded readings below 25 PSU in three sampling months as July 2017, January 2018 and February 2018 (Figure 2d). High readings of turbidity were recorded in July 2017, September 2017, October 2017 and January 2018 with range between 126.67 NTU and 530.67 NTU (Figure 2e). Low turbidity readings were measured in November 2017, March 2018 and April 2018, ranging from 12.60 NTU until 188 NTU. Figure 3 shows the mean of selected ex-situ water quality parameters in Miri coastal water between May 2017 and April 2018. TSS results show similar pattern as turbidity with $26 \mathrm{mg} / \mathrm{L}-561 \mathrm{mg} / \mathrm{L}$

Table 1. Coordinate and brief descriptions of each station

\begin{tabular}{|c|c|c|}
\hline Station & Coordinate & Brief descriptions \\
\hline 1 & 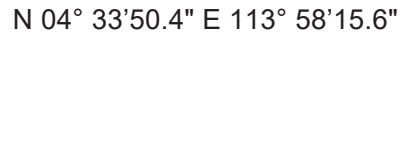 & $\begin{array}{l}\text { - Near the mouth of Baram River } \\
\text { - Sandy beach along the coastline } \\
\text { Presence of black, small fragments of wood and branches at } \\
\text { the water bottom }\end{array}$ \\
\hline 2 & N $04^{\circ} 33^{\prime} 11.8^{\prime \prime}$ E $113^{\circ} 58^{\prime} 28.6^{\prime \prime}$ & - Sandy beach along the coastline \\
\hline 3 & N 043'ㄹ. $27.4^{\circ}$ E $113^{\circ} 59^{\prime} 05.3^{\prime \prime}$ & - Located near small river \\
\hline 4 & N $04^{\circ} 29^{\prime} 47.8^{\prime \prime}$ E $113^{\circ} 59^{\prime} 28.1^{\prime \prime}$ & - Located near Batu 1 jetty and fish market \\
\hline
\end{tabular}




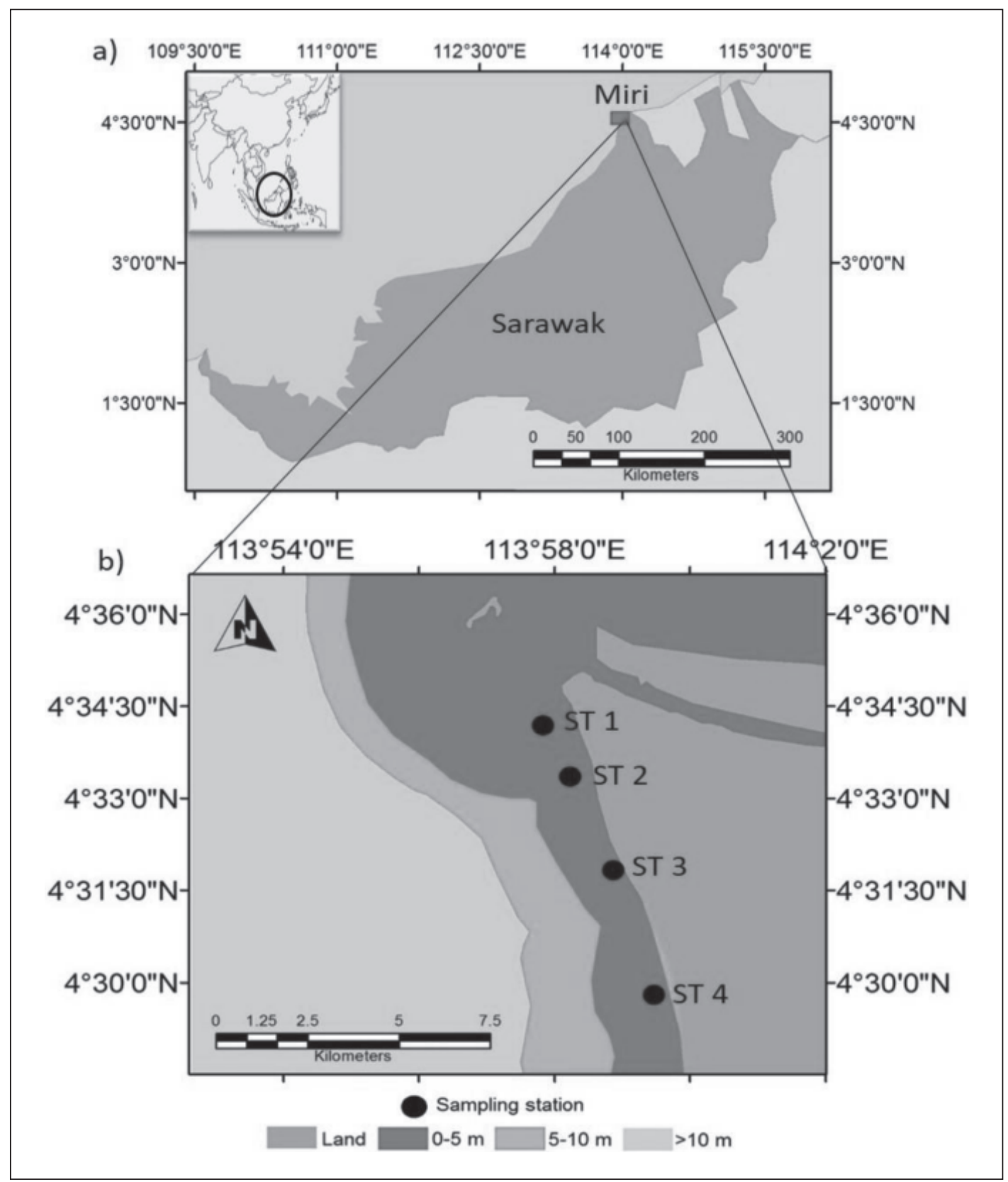

Fig. 1. (a) Map of Sarawak; (b) The black dot indicates the sampling stations in Miri, Sarawak (ST1-ST4).

Table 2. Range of selected in-situ and ex-situ water quality parameters for every station in Miri coastal water, Sarawak

\begin{tabular}{lcccc}
\hline & ST1 & ST2 & ST3 & ST4 \\
\hline Temperature $\left({ }^{\circ} \mathrm{C}\right)$ & $29.0-31.5$ & $27.0-32.0$ & $26.9-32.0$ & $27.3-33.2$ \\
DO $(\mathrm{mg} / \mathrm{L})$ & $4.48-7.22$ & $5.31-7.05$ & $4.92-7.02$ & $5.09-7.31$ \\
pH & $7.03-8.32$ & $7.07-8.23$ & $7.12-8.19$ & $6.98-8.18$ \\
Salinity (PSU) & $5-35$ & $5-35$ & $5-35$ & $17-35$ \\
Turbidity (mg/L) & $22.22-530.67$ & $9.23-502.50$ & $10.99-392.67$ & $10.67-492.33$ \\
TSS $(\mathrm{mg} / \mathrm{L})$ & $52-537$ & $37-343$ & $36-561$ & $26-0335$ \\
$\mathrm{Chl} \mathrm{a}\left(\mathrm{mg} / \mathrm{m}^{3}\right)$ & $0.66-2.72$ & $0.43-2.22$ & $0.61-2.31$ & $0.66-2.45$ \\
$\mathrm{NO}_{3}^{-}(\mathrm{mg} / \mathrm{L})$ & $0.00-0.08$ & $0.00-0.05$ & $0.01-0.02$ & $0.00-0.06$ \\
$\mathrm{PO}^{3-}(\mathrm{mg} / \mathrm{L})$ & $0.01-0.24$ & $0.03-0.55$ & $0.02-0.35$ & $0.02-0.23$ \\
\hline
\end{tabular}

DO: Dissolved oxygen, TSS: Total suspended solids. 


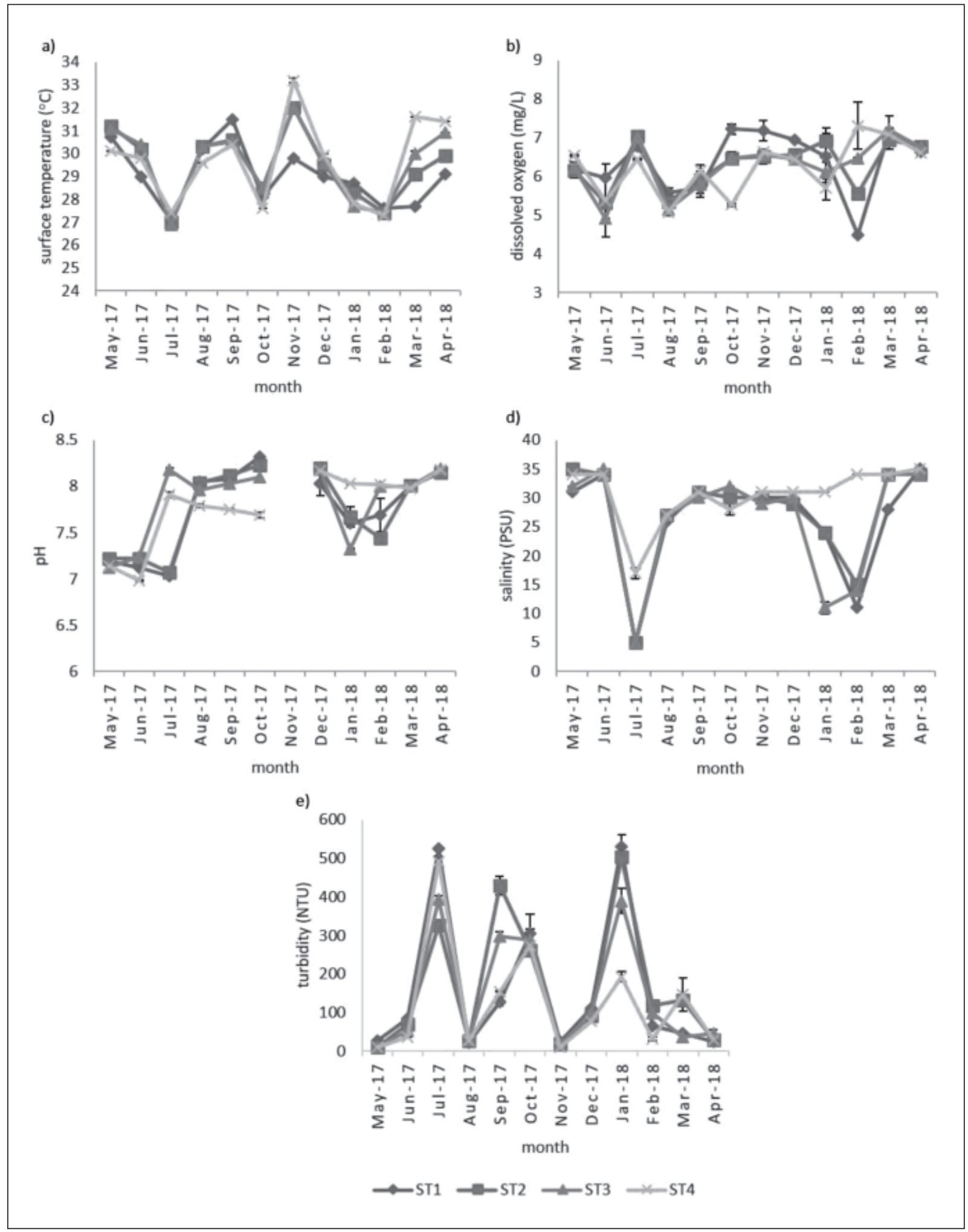

Fig. 2. Mean of selected in-situ water quality parameters in Miri coastal water from May 2017 until April 2018. (a) temperature; (b) DO; (c) pH; (d) salinity; (e) turbidity.

(Figure 3a). For chl $a$, the readings show fluctuate pattern throughout the sampling period with range of $0.4262-2.7219 \mathrm{mg} / \mathrm{m}^{3}$ (Figure 3b).

According to the Principal Component Analysis for selected surface water quality parameters in Miri coastal water, the variation was best explained by the principal component 1 (PC1) and principal component 2 (PC2) with total variances of $55.95 \%$. PC1 has total variance of $34.07 \%$ while PC2 has total variance of $21.88 \%$. 


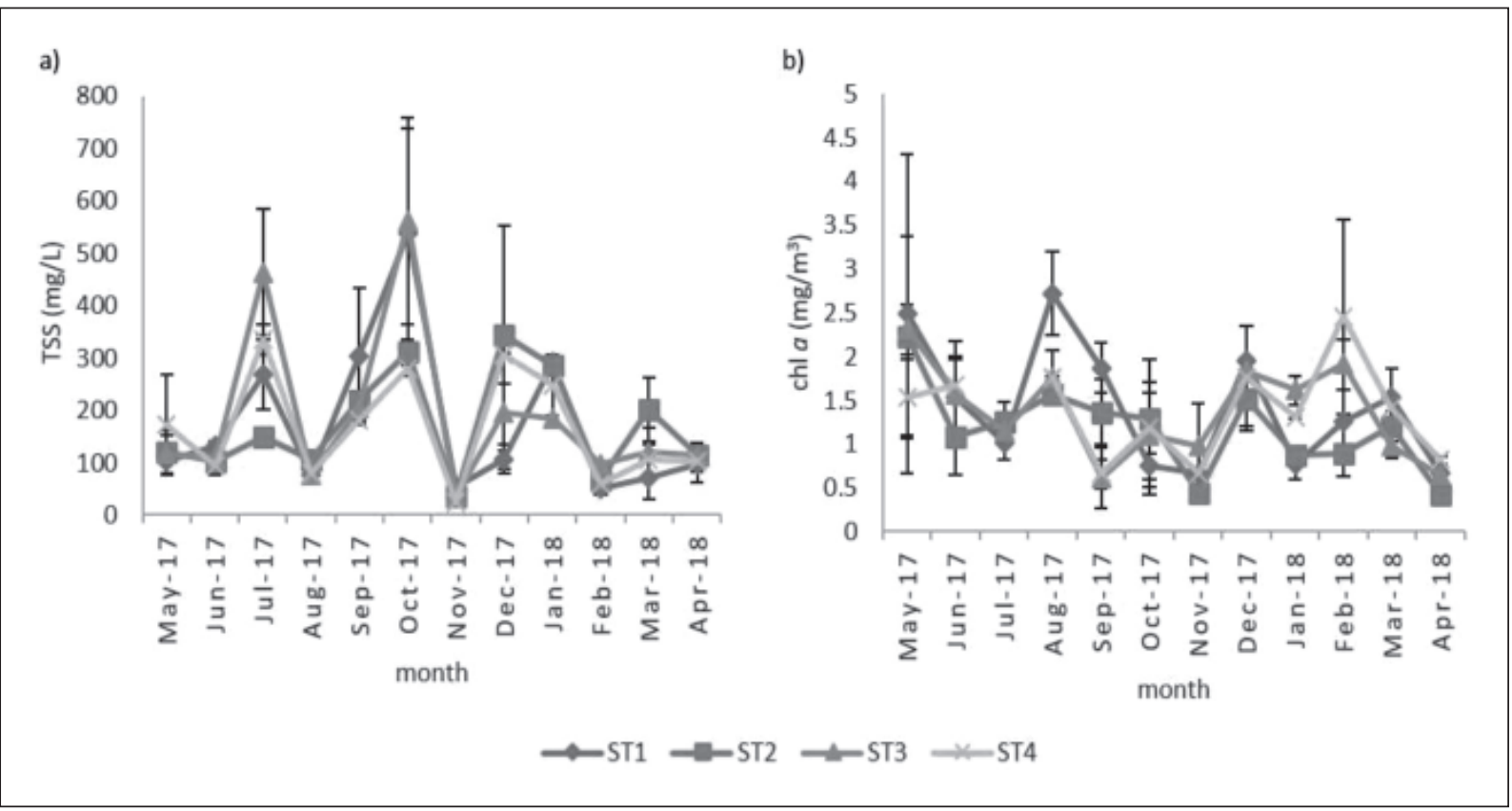

Fig. 3. Mean of selected in-situ water quality parameters in Miri coastal water from May 2017 until April 2018. (a) TSS, (b) chl $a$, TSS: Total suspended solids.

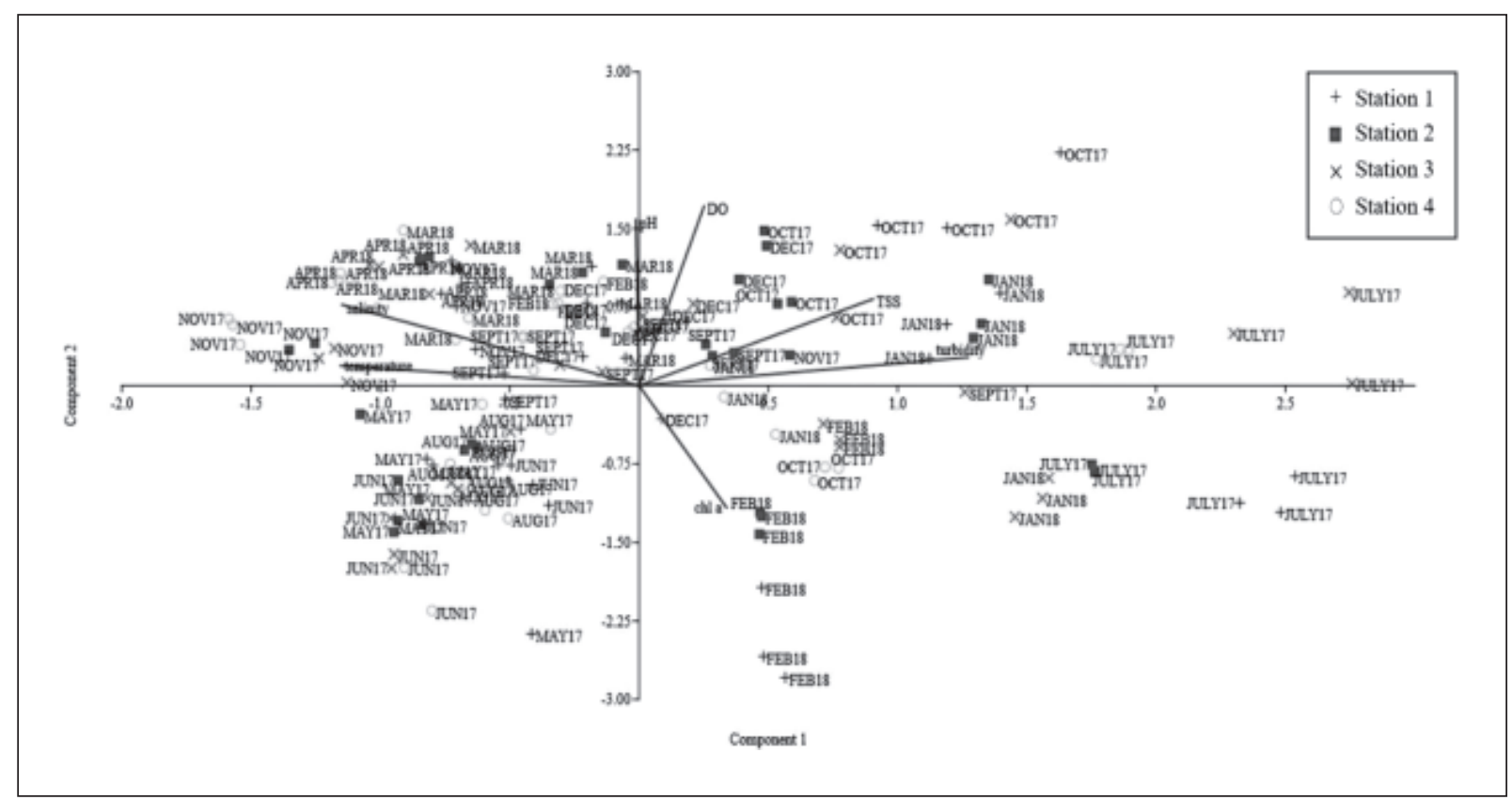

Fig. 4. Biplot diagram of Principal Component Analysis for selected surface water quality parameters. Total variance explained by the two axes is $55.954 \%$.

Based on biplot diagram of PC1 (Figure 4), the waters in four sampling months namely July 2017, September 2017, October 2017, December 2017 and January 2018 were characterized with high turbidity, high TSS, low temperature and low salinity. In contrast, three sampling months namely November 2017, March 2018 and April 2018 had clear and warmer water with high salinity level. Based on biplot diagram of PC2 (Figure 4), the coastal water of Miri in May 2017 and June 2017 had low pH level.

In general, ST1 until ST4 in Miri coastal water fall in Class E of Malaysian Marine Water Quality Standards (MMWQS). Table 3 shows the comparison between surface water quality results in every station along Miri coastal water with Class E of MMWQS. ST1 and ST4 had higher DO values 
Table 3. Comparison of surface water quality results in ST1-ST4, Miri, Sarawak with Malaysian Marine Water Quality Standards (MMWQS)

\begin{tabular}{lccccr}
\hline & Station & DO $(\mathrm{mg} / \mathrm{L})$ & TSS $(\mathrm{mg} / \mathrm{L})$ & Temperature $\left({ }^{\circ} \mathrm{C}\right)$ & $\mathrm{pH}$ \\
\hline Reference value (Class E) & & $>5.0$ & 30.0 & $\begin{array}{l}2^{\circ} \mathrm{C} \text { increase over } \\
\text { maximum ambient }\end{array}$ & $6.5-9.0$ \\
& & & & & \\
Observed value & ST1 & $4.48-7.22$ & $52-537$ & $29.0-31.5$ & $7.03-8.32$ \\
& ST2 & $5.31-7.05$ & $37-343$ & $27.0-32.0$ & $7.07-8.23$ \\
& ST3 & $4.92-7.02$ & $36-561$ & $26.9-32.0$ & $7.12-8.19$ \\
& ST4 & $5.09-7.31$ & $26-335$ & $27.3-33.2$ & $6.98-8.18$ \\
\hline
\end{tabular}

DO: Dissolved oxygen, TSS: Total suspended solids.

compared to the standard value of Class E while few sampling months in ST1 and ST3 recorded low DO values compared to the standard value. The range of TSS in ST1, ST2 and ST3 were higher compare to the standard value of Class E. Meanwhile, the range of $\mathrm{pH}$ recorded in all sampling stations were within the range of standard value for Class E.

\section{DISCUSSION}

Based on PC1, the water in July 2017 (ST3, ST4), September 2017 (ST2, ST3), October 2017 (ST1, ST2, ST3), December 2017 (ST1, ST2, ST3) and January 2018 (ST1, ST2) were cooler, turbid and had low salinity level compare to the other sampling months. The characteristics mentioned above could be explained by several reasons. First, low temperature recorded is due to measurement taken during cloudy weather that limit direct sunlight onto the surface water. Second, there was a large volume of water runoff from Kuala Baram River especially during sampling month in July 2017, leading to low salinity reading (4 PSU). Data of daily rainfall obtained from Malaysian Meteorological Department showed that Miri areas had received rainfall between $0.2 \mathrm{~mm}$ to $48.0 \mathrm{~mm}$, daily, in that particular month. Besides, water runoff from a small river, located at ST3 could also caused the reduction in salinity readings. Turbid water in all sampling months is due to water runoff from Kuala Baram River that brought high sediment load from the upper river into Miri coastal water. According to Argawal and Rajwar (2010) and Gasim et al. (2006), soil erosion frequently happen within the area of agriculture and logging activities, where the forest clearing could cause the soil to loss support from the tree roots. Jonnalagadda and Mhere (2001) reported that the problem could worsen during rainfall and rainy season. Human activities along Kuala Baram River such as agriculture farms, log factories, shipyards and ports could lead to water sedimentation, resulting in high turbidity and low salinity in Miri coastal water. In addition, October 2017 and January 2018 were within northeast monsoon (October until March) where rainfall frequently happen in Sarawak (Sa'adi et al., 2017).

Based on PC1, all sampling stations in November 2017, March 2018 and April 2018 had clear and warmer waters with high salinity level. Wong et al. (2012) reported that salinity fluctuates depending on the freshwater runoff from river and input of precipitation. During the sampling months of November 2017, March 2018 and April 2018, less water runoff from the river with relatively low in sediment content, consequently Miri coastal water become clear and the salinity readings were high. The monthly rainfall for particular sampling months was between $208 \mathrm{~mm}$ and $334 \mathrm{~mm}$, showing less input of precipitation compare to the other sampling months. According to Dallas (2008), an area exposed to direct sunlight especially during hot weather could increase the water temperature. During the current study, the measurements were taken during sunny weather. Besides, the stations are an open area without any form of shade where the water temperature could increase as high as $33.3^{\circ} \mathrm{C}$ during hot weather. Drainage runoff from shipyard and timber factories including palm oil plantation along Baram River could also lead to the increase in TSS in coastal area; the sediment particles absorbed the light and eventually the water become warmer.

The result of PC2 shows that all the stations in May 2017 and June 2017 were characterized with low pH readings. pH in May 2017 and June 2017 ranged from 7.09 to 7.22 and 6.99 to 7.24 , respectively. Suratman et al. (2014) reported that an increasing of decomposition rate of organic matter could reduce the water $\mathrm{pH}$. According to Gasim et al. (2006), runoff of decaying vegetation could cause high decomposition rate. Therefore, low $\mathrm{pH}$ observed in May 2017 and June 2017 could be due to excessive discharge from Kuala Baram River, which comprised of wood fragments. These fragments increase the decomposition rate leading to low of $\mathrm{pH}$ reading. Another reason for low $\mathrm{pH}$ in that particular sampling months was due to high water temperature. May 2017 and June 2017 recorded temperature of $30.1^{\circ} \mathrm{C}-31.2^{\circ} \mathrm{C}$ and $29.0^{\circ} \mathrm{C}-30.4^{\circ} \mathrm{C}$, 
respectively. The increase in water temperature promotes the ability of water to ionize, adding more hydrogen ions that lower the water $\mathrm{pH}$ reading.

The importance of phytoplankton in marine food web has been reported in many literatures (Nurul Amin \& Arshad, 2010; Oh et al., 2011; Saini, 2013). Chl $a$ concentration in this current study shows fluctuating patterns with the lowest values were recorded in March and April 2018 which coincided with the bloom of sergestid shrimps in the area (Othman et al., 2020).

Coastal communities in Miri rely on sergestid shrimps bloom for extra income and the phenomenon happens yearly in March and April (Othman et al. 2020). Local knowledge stated that warm and clear waters after stormy Northwest monsoon are the cues for sergestid shrimps. Findings in this study is the scientific evidence to support that local knowledge as months March and April (inter-monsoon) had recorded warmer and clearer water with relatively high salinity reading. For future works, the interaction between sergestid shrimp and water qualities could be observed to determine the factors that influence the blooming of this valuable resource.

\section{CONCLUSION}

The water qualities in Miri coastal water fluctuated according to the weather, condition of the sea and volume of river water runoff into the coastal area. Nevertheless, the quality of the water quality parameters still remained within the range of standard value of Class E of MMWQS.

\section{ACKNOWLEDGEMENTS}

This work is supported by UNIMAS-UMS collaboration work Grant Scheme GL/F07/UMS/06/ 2017. Authors would like to thank local people of Batu 1 village and UNIMAS postgraduate students for their kind assistance during sampling trips. Thank you to UNIMAS for laboratory facilities.

\section{REFERENCES}

Aminot, A. \& Rey, F. 2000. Standard procedure for the determination of chlorophyll $a$ by spectroscopic methods. ICES Techniques in Marine Environmental Sciences, 1-17.

Argawal, A.L. \& Rajwar, G.S. 2010. Physico-chemical and microbiological study of Tehri dam reservoir, Garhwal Himalaya, India. Journal of American Science, 6: 65-71.
Burke, L., Kura, Y., Kassem, K., Revenga, C., Spalding, M. \& McAllister, D. 2001. Coastal Ecosystems. World Resources Institute, Washington.

Cochard, R. 2016. Coastal water pollution and its potential mitigation by vegetated wetlands/: An overview of issues in Southeast Asia. In: Redefining Diversity and Dynamics of Natural Resources Management in Asia. G. Shivakoti, U. Pradhan \& H. Helmi (Eds.). Elsevier Inc. pp. 189-230.

Dallas, H. 2008. Water temperature and riverine ecosystems: An overview of knowledge and approaches for assessing biotic responses, with special reference to South Africa. Water $S A$, 34(3): 393-404.

Ee, T.F. \& Zae, L.V. 2010. A study of coastal areas in Miri, Sarawak, in: Conference of Natural Resources and Green Technology. Kuching, Sarawak, pp. 56-65.

Gasim, M.B., Toriman, M.E., Rahim, S.A., Islam, M.S., Tan, C.C. \& Juahir, H. 2006. Hydrology, water quality and land-use assessment of Tasik Chini's feeder rivers, Pahang, Malaysia. Malaysian Journal of Society and Space, 2: 72-86.

Green, D.R. \& Payne, J.L. 2017. Marine and Coastal Resource Management: Principles and Practice. Routledge, New York.

Hach. 2007. DR2800 spectrophotometer procedures manual. URL www.hach.com/asset-get.download. jsa? id $=7639982436$ (accessed 1.1.2018).

Jacobs. 2010. Standard operating procedure: Total suspended solids determination using vacuum filtration and oven drying [WWW Document]. URL http://waterfacts.net/Treatment/Activated Sludge/Wastewater_Tests/TSS/TVA-KIF-SOP 49_Total_Suspended_Solids_Apr_10_.pdf (accessed 1.1.2018).

Jonnalagadda, S.B. \& Mhere, G. 2001. Water quality of the Odzi river in the Eastern Highlands of Zimbabwe. Water Research, 35(10): 2371-2376.

Le Tissier, M.D.A., Buddemeier, R., Parslow, J., Swaney, D.P., Crossland, C.J., Smith, S.V, Whyte, H.A.Y., Dennison, W.C., Hills, J.M. \& Kremer, H.H. 2006. The Role of The Coastal Ocean in The Disturbed and Undisturbed Nutrient and Carbon Cycles-A Management Perspective. LOICZ, Geesthacht.

Nurul Amin, S.M. \& Arshad, A. 2010. Biology and Population Dynamics of Sergestid Shrimps. LAP LAMBERT Academic Publishing, Saarbrucken. 
Oh, S.Y., Arshad, A., Japar, S.B., Nor Azwady, A.A. \& Amin, S.M.N. 2011. Diet composition of sergestid shrimp Acetes serrulatus from the coastal waters of Kukup, Johor, Malaysia. Journal of Fisheries and Aquatic Science, 6(7): 809-815.

Othman, M.N.A., Hassan, R. \& Chen, C.A. 2020. Checklist of Sergestid shrimps, Acetes (Decapoda: Sergestidae) from selected sites along the coastal water of Sarawak, Malaysia. Malayan Nature Journal, 72(1): 121-131.

Sa'adi, Z., Shahid, S., Ismail, T., Chung, E.S. \& Wang, X.J. 2017. Distributional changes in rainfall and river flow in Sarawak, Malaysia. Asia-Pacific Journal of Atmospheric Sciences, 53(4): 489-500.

Saini, M. 2013. Feeding Habits, Recruitment and Status of Sergestid Shrimps (Acetes intermedius Omori) Stock in Bintulu, Sarawak (Master). Universiti Putra Malaysia.
Suratman, S., Hussein, A.N.A.R., Latif, M.T. \& Weston, K. 2014. Reassessment of physicochemical water quality in Setiu Wetland, Malaysia. Sains Malaysiana, 43(8): 1127-1131.

Tanjung, R.H.R., Hamuna, B. \& Alianto. 2019. Assessment of water quality and pollution index in coastal waters of Mimika, Indonesia. Journal of Ecological Engineering, 20(2): 87-94.

Wong, S.C., Muta Harah, Z., Japar Sidik, B. \& Arshad, A. 2012. Comparison of seaweed communities of the two rocky shores in Sarawak, Malaysia. Coastal Marine Science, 35(1): 7884. 